\title{
The Presence of Diverse IS Elements and an avrPphD Homologue That Acts as a Virulence Factor on the Pathogenicity Plasmid of Erwinia herbicola pv. gypsophilae
}

\author{
Ming Guo, ${ }^{1}$ Shulamit Manulis, ${ }^{2}$ Henia Mor, ${ }^{1}$ and Isaac Barash ${ }^{1}$ \\ ${ }^{1}$ Department of Plant Sciences, Faculty of Life Sciences, Tel Aviv University, 69978 Israel, and ${ }^{2}$ Department of Plant \\ Pathology, ARO, the Volcani Center, Bet Dagan 50250, Israel
}

Submitted 25 January 2002. Accepted 18 March 2002.

The pathogenicity of Erwinia herbicola pv. gypsophilae (Ehg) and Erwinia herbicola pv. betae (Ehb) is dependent on a native plasmid (pPATH Eng $_{\text {or }}$ pPATH $_{\text {Ehb }}$ ) that harbors the $h r p$ gene cluster, genes encoding type III effectors, phytohormones, biosynthetic genes, and several copies of IS1327. Sequence analysis of the $h r p$-flanking region in pPATH $_{\text {Ehg }}$ (cosmid pLA150) revealed a cluster of four additional IS elements designated as ISEhe1, ISEhe2, ISEhe3, and ISEhe4. Two copies of another IS element (ISEhe5) were identified on the upstream region of the indole-3-acetic acid operon located on the same cosmid. Based on homology of amino acids and genetic organization, ISEhel belongs to the IS630 family, ISEhe2 to the IS5 family, ISEhe 3 and ISEhe4 to different groups of the IS3 family, and ISEhe5 to the IS1 family. With the exception of ISEhe4, one to three copies of all the other IS elements were identified only in pathogenic strains of Erwinia herbicola pv. gypsophilae and Erwinia herbicola pv. betae whereas ISEhe4 was present in both pathogenic and nonpathogenic strains. An open reading frame that exhibited high identity (89\% in amino acids) to AvrPphD of Pseudomonas syringae pv. phaseolicola was present within the cluster of IS elements. An insertional mutation in the $A v r P p h D_{\text {Eng }}$ reduced gall size in gypsophila by approximately $85 \%$. In addition, remnants of known genes from four different bacteria were detected on the same cosmid.

Additional keywords: cytokinins, Pantoea agglomerans.

Erwinia herbicola (Pantoea agglomerans) is widespread in nature as an epiphyte on many different plants (Gavini et al. 1989; Starr 1981). In addition to its prevalence on plant surfaces, it has been characterized as an endophyte in grapevine (Bell et al.1995) and has been isolated from seeds, water, humans, and animals (Gavini et al. 1989). Some strains of Erwinia herbicola have evolved into tumorigenic bacteria that incite gall formation on gypsophila (Gypsophila paniculata L.) (Cooksey 1986) and beet (Beta vulgaris L.) (Burr et al. 1991). The host range of Erwinia herbicola pv. gypsophilae (Ehg) is restricted to gypsophila (Volcani 1985) whereas the beet pathovar, Erwinia herbicola pv. betae (Ehb) elicits galls on both beet and gypsophila (Burr et al. 1991). Other pathovars of

Corresponding authors: I. Barash; E-mail: isaaci@post.tau.ac.il; S. Manulis; E-mail: shulam@netvision.net.il.
Erwinia herbicola that cause galls on Wisteria (Opgenorth et al. 1994), Douglas fir (De Young et al. 1998) and cranberry (Vasanthakumar and McManus 2001) have also been reported. The pathogenicity of Erwinia herbicola pv. gypsophilae or Erwinia herbicola pv. betae depends on a similar large indigenous plasmid (designated as pPATH $\mathrm{Ehg}_{\text {or }} \mathrm{PPATH}_{\mathrm{Ehb}}$ ) that is present in all pathogenic, but not in nonpathogenic, strains (Manulis et al. 1991; I. Barash and S. Manulis, unpublished

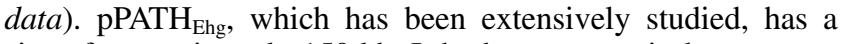
size of approximately $150 \mathrm{~kb}$. It harbors many virulence genes that can be divided into three groups: an hrp gene cluster (Mor et al. 2001; Nizan et al. 1997), genes encoding type III effectors that are involved in pathogenicity and host specificity (Ezra et al. 2000; Mor et al. 2001; Valinsky et al. 1998), and genes encoding biosynthetic pathways for indole-3-acetic acid (IAA) and cytokinins (Clark et al. 1993; Gafni et al. 1997; Lichter et al. 1995a). All these genes are located on three successive and overlapping cosmids that occupy approximately 55 $\mathrm{kb}$ of the pPATH $\mathrm{Eng}_{\text {Eng }}$ and that could be conceived as a pathogenicity island.

During recent years, the concept of pathogenicity islands (PAIs) has emerged to describe genomic regions of pathogens carrying virulence genes together with loci whose presence strongly indicates horizontal gene transfer between species or even genera (Hacker and Kaper 1999). PAIs are typically present in genomes of pathogenic bacteria but not in those of nonpathogenic members of the same or closely related species. The definition of PAIs originally included chromosomal location (Hacker et al. 1997), but the increasing volume of sequence data available for virulence plasmids supports the view that parts of them can also be considered to be PAIs (Hacker and Kaper 1999). Examples include plasmid-borne PAIs in bacteria pathogenic on animals (Iriarte and Cornelis 1999; Parsot and Sansonetti 1999) and on plants (Jackson et al. 1999; Winans et al. 1999).

Type III secretion systems play an essential role in the virulence of most gram-negative pathogenic bacteria and are closely associated with PAIs (Hacker and Kaper 2000). Moreover, it is now assumed that bacteria acquire pathogenicity not by slow adaptive evolution but by "quantum leaps" that enable them to acquire complete virulence systems in the course of one or a few steps (Mecsas and Strauss 1996). Consequently, the flanking regions of the hrp/type III gene clusters in phytopathogenic bacteria are of particular interest because they may provide valuable information on PAIs evolution and may help to identify type III effectors or other genes that could contrib- 
ute to virulence (Alfano et al. 2000). Cosmid pLA150 of the pPATH $_{\text {Ehg }}$ has previously been shown to encompass the hrpJ operon (Nizan et al. 1997), a host-specific virulence gene $h s v G$ (Valinsky et al. 1998), a cluster of IAA and cytokinin biosynthesizing genes (Clark et al. 1993; Lichter et al. 1995a), and two copies of insertion sequences (IS) designated as IS1327 that belong to the IS6 family (Lichter et al. 1996) (Fig. 1). Therefore, we considered the possibility that pLA150 might possess additional loci associated with either virulence or sequences acquired by horizontal gene transfer The present study supports the latter hypothesis and demonstrates that this cosmid contains additional multiple and diverse IS elements, an avrPphD homologue of Psuedomonas syringae pv. phaseolicola that acts as a virulence factor, and remnants of foreign genes from different bacteria. Furthermore, additional evidence was found that substantiates the presence of a PAI on pPATH $\mathrm{Ehg}_{\mathrm{E}}$.

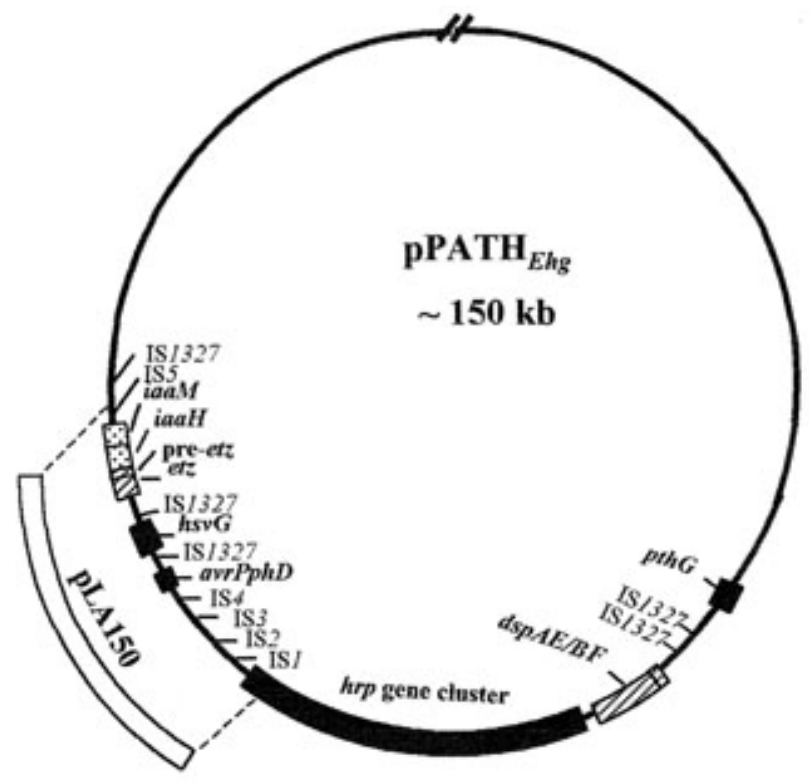

\section{pLA150}
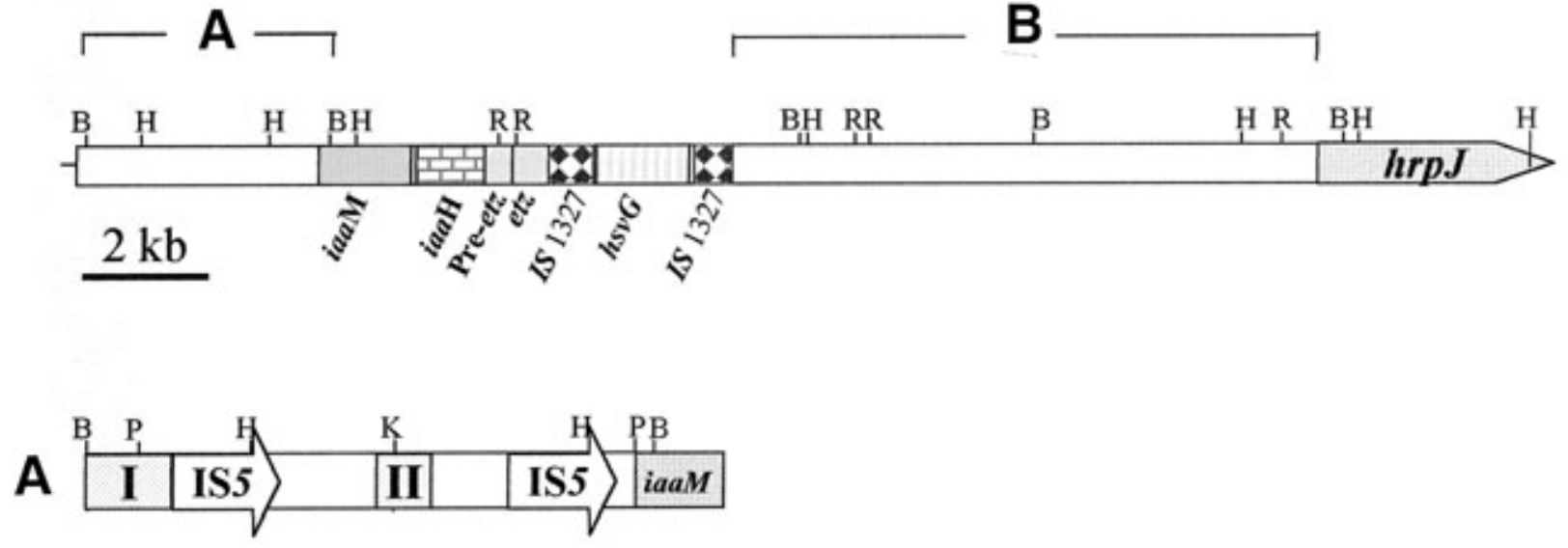

\section{$1 \mathrm{~kb}$}

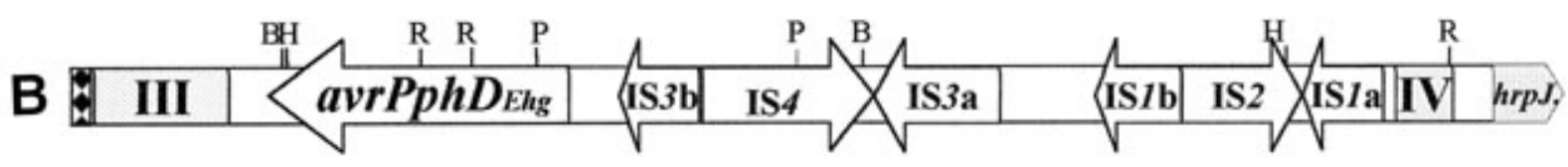

Fig. 1. Schematic map of the pathogenicity plasmid pPATH $\mathrm{Ehg}_{\mathrm{g}}$ and physical map of its cosmid clone pLA150. Previously identified genes and IS element: $i a a M$ and $i a a H$ (indole-3-acetic acid biosynthesizing genes); pre-etz and etz (cytokinin biosynthesizing genes); $h s v G, d s p A E / B F, p t h G$ (type III virulence effectors); $h r p J$ operon, and IS1327. A, Enlarged sequenced DNA region (4 kb) upstream to iaaM. B, Enlarged sequenced $h r p$-flanking DNA region (10 $\mathrm{kb})$ extending between $\mathrm{hrpJ}$ and IS1327. Open arrows signify the location and orientation of the newly identified IS elements: IS1-ISEhe1, IS2-ISEhe2, IS3-ISEhe3, IS4-ISEhe4, and IS5-ISEhe5 (two copies). IS $1 \mathrm{a}$ and IS $1 \mathrm{~b}$ are two parts of ISEhe1 that were disrupted by ISEhe2, whereas IS3a and IS3b are two parts of ISEhe3 that were disrupted by ISEhe4. avrPphD $D_{\mathrm{Ehg}}$ is a homologue of the avrPphD reported in Pseudomonas syringe pv. phaseolicola. Roman numerals I to IV in gray boxes indicate residual gene sequences acquired from a variety of bacteria. $\mathrm{R}=$ Eco RI, $\mathrm{B}=$ Bam HI, $\mathrm{P}=P$ stI, $\mathrm{H}=H i n \mathrm{dIII}$, $\mathrm{K}=K p n \mathrm{I}$ 


\section{RESULTS}

Characterization of new IS elements on cosmid pLA150.

To determine whether additional virulence genes or IS elements are present on pLA150, we sequenced the region upstream to the iaaM gene (Fig. 1A) and the flanking region of the hrp gene cluster between the hrpJ operon and IS1327 (Fig. $1 \mathrm{~B})$, as described below. In addition to two copies of the previously described IS1327 (Lichter et al. 1996), five new IS elements were characterized (Table 1). According to their distance from the hrp gene cluster, they were designated as ISEhe1 to ISEhe 5 as suggested by the IS finder Internet website. Classification of the IS elements into families and groups was based on similarities in their putative transposases (Table 1), the presence of common domains (not shown), and similarities in genetic organization (arrangement of open reading frames [ORFs]) (Table 1) as described by Mahillon and Chandler (1998). Accordingly, as shown in Table 1, ISEhel was allocated to the IS630 family with the highest homology in amino acids (84\%) to IS630 from Shigella sonnei (Hu-Shu and Malabi 1998); ISEhe 2 to the IS5 family with the highest homology (52\%) to IS427 from Agrobacterium tumefaciens (de Meirsman et al. 1990); ISEhe3 to the IS3 family (group IS3) with the highest homology (59\%) to an IS3-like element from A. tumefaciens (Otten and Schmidt 1998); ISEhe4 to IS3 (group IS407) with the highest homology (95\%) to IS122 from Enterobacter agglomerans (Steibl and Lewecke 1995); and ISEhe 5 to the IS 1 family with the highest homology (47\%) to IS1 of Shigella dysenteriae (Ohtsubo et al. 1981). With the exception of ISEhe 1, which carries a single transposase, all the IS elements accommodate two transposases (Table 1).

The $\mathrm{G}+\mathrm{C}$ contents of ISEhe1, ISEhe2, ISEhe3, ISEhe4, and ISEhe5 (in mole percentages) were 49.2, 51.2, 47.7, 53.9, and 43.9, respectively, as compared with $\mathrm{G}+\mathrm{C}$ contents of 55.1 to 56.8 mole\% for Erwinia herbicola (Pantoea agglomerans) (Gavini et al. 1989). The continuities of ISEhe 1 and ISEhe 3 were interrupted by insertion of ISEhe 2 and ISEhe4, respectively (Fig. 1B). The latter sequence organization could indicate that the horizontal transfer of ISEhe 1 and ISEhe 3 into the $\mathrm{PPATH}_{\text {Ehg }}$ preceded that of ISEhe2 and
ISEhe4. It is also noteworthy that ISEhe 5 was present in two copies on pLA150 (Fig. 1A).

In addition to the IS elements and the $a v r P p h D$ homologue (i.e., avrPphD $\mathrm{D}_{\text {Ehg }}$ ) to be described below, four remnants of known gene sequences (designated I to IV) from various bacteria were identified (Fig. 1). These include residual sequences that exhibited $75 \%$ homology (per 193 amino acids [aa]) with the coagulase/fibrinolysin precursor from Yersinia pestis (accession number AL109969), 50\% homology (per 120 aa) with hypothetical protein from Xylella fastidiosa (accession number AE004024), 68\% homology (per 290 aa) with conserved hypothetical protein 1 of Actinobacillus pleuropneumoniae (accession number AF282240) (Cheng et al. 2000), and 52\% homology (per 115 aa) with a putative transposase from Escherichia coli (accession number AE005345).

\section{Distribution of the IS elements in pathogenic and nonpathogenic strains of Erwinia herbicola.}

The presence and the copy number of newly identified IS elements in pathogenic (Ehg824-1, Ehg3-1a, Ehb4188) and nonpathogenic (Eh3-1, Eh24-8, EhK4, Eh27-3, Eh717-2, Eh3106) strains of Erwinia herbicola were determined by digesting the total DNA of each strain with EcoRI, HindIII, and BamHI, and then performing a Southern blot hybridization with IS-specific probes. An example of a Southern blot hybridization obtained with HindIII digests of three pathogenic and two nonpathogenic strains are illustrated in Figure 2. Results summarized in Table 2 indicate that ISEhe1, ISEhe2, ISEhe3, and ISEhe 5 were present only in pathogenic strains, whereas ISEhe4 was present in both pathogenic and nonpathogenic strains. The nonpathogenic strain Eh3-106 is a Tn5 derivative of Ehg824-1 with a deletion of 40 to $50 \mathrm{~kb}$ in the pPATH $_{\text {Eng }}$ region upstream to the etz gene (Lichter et al. 1995b). Thus it does not contain the 2 copies of ISEhe 5 located upstream to the iaaM gene (Fig. 1A) but still accommodates more than $100 \mathrm{~kb}$ of the pPATH $\mathrm{Ehg}_{\mathrm{E} g}$ on which the other IS elements were present All the IS elements also appeared in the beet pathovar (Ehb4188). The copy numbers of the various IS elements among the different Erwinia strains ranged from one to three with the exception of ISEhe3 in Ehb4188, which

Table 1. New IS elements characterized on the pLA150 cosmid of pPATH

\begin{tabular}{|c|c|c|c|c|c|c|}
\hline $\begin{array}{l}\text { IS elements/ } \\
\text { accession no. }\end{array}$ & $\begin{array}{c}\text { ORF }^{\mathbf{a}} \\
\text { (bp) }\end{array}$ & $\begin{array}{c}\text { Inverted } \\
\text { repeats }\end{array}$ & Family & Group & Possible sources (homology) ${ }^{b}$ & Reference or accession no. \\
\hline \multirow{2}{*}{$\begin{array}{l}\text { ISEhe 1 } \\
\text { AF326767 }\end{array}$} & 525 & $21 / 21$ & IS630 & IS630 & Shigell a sonnei IS630 (84\%) & Hu-Shu and Malabi 1998 \\
\hline & & & & & $\begin{array}{l}\text { Salmonella choleraesuis }(62 \%) \\
\text { Salmonella typhimurium }(61 \%)\end{array}$ & $\begin{array}{l}\text { BAA01531.1 } \\
\text { Krause et al.1991 }\end{array}$ \\
\hline \multirow{2}{*}{$\begin{array}{l}\text { ISEhe 2 } \\
\text { AF327444 }\end{array}$} & A-449 & $23 / 22$ & IS5 & IS427 & Streptomyces coelicolor IS1648 and IS1650 (50\%) & Redenbach et al. 1996 \\
\hline & B-515 & & & & $\begin{array}{l}\text { Agrobacterium tumefaciens IS427 (52\%) } \\
\text { Mycobacterium tuberculosis ISMt } 1(42 \%)\end{array}$ & $\begin{array}{l}\text { de Meirsman et al. } 1990 \\
\text { Mariani et al. } 1993\end{array}$ \\
\hline \multirow[t]{2}{*}{$\begin{array}{l}\text { ISEhe3 } \\
\text { AF327445 }\end{array}$} & $\begin{array}{l}\text { A-284 } \\
\text { B-839 }\end{array}$ & $20 / 20$ & IS3 & IS3 & Erwinia amylovora ISEam1 (51\%) & McGhee and Jones 2000 \\
\hline & & & & & $\begin{array}{l}\text { Agrobacterium tumefaciens IS3-like (59\%) } \\
\text { Yersinia enterocolitica IS1329 (43\%) } \\
\text { Shigella sonnei IS600 (40\%) }\end{array}$ & $\begin{array}{l}\text { Otten and Schmidt } 1998 \\
\text { Carniel et al. } 1996 \\
\text { Matsutani et al. } 1987\end{array}$ \\
\hline \multirow[t]{2}{*}{$\begin{array}{l}\text { ISEhe4 } \\
\text { AF324174 }\end{array}$} & $\begin{array}{l}\text { A-263 } \\
\text { B-824 }\end{array}$ & $26 / 25$ & IS3 & IS407 & Enterobacter agglomerans IS1222 (95\%) & Steibl and Lewecke 1995 \\
\hline & & & & & $\begin{array}{l}\text { Pseudomonas cepacia IS407 (69\%) } \\
\text { Xanthomonas campestris pv. campestris (58\%) } \\
\text { Xanthomonas campestris pv. amaranthicola }(59 \%) \\
\text { Rhizobium spp ISR } 1 \text { (59\%) }\end{array}$ & $\begin{array}{l}\text { Wood et al. } 1991 \\
\text { Lee and Chiu } 1998 \\
\text { Gomez et al. } 1997 \\
\text { Priefer et al. } 1989\end{array}$ \\
\hline \multirow[t]{2}{*}{$\begin{array}{l}\text { ISEhe 5 } \\
\text { AF327446 }\end{array}$} & $\begin{array}{l}\text { A-275 } \\
\text { B-506 }\end{array}$ & $30 / 30$ & IS1 & & Shigella dysenteriae IS1 (47\%) & Ohtsubo et al. 1981 \\
\hline & & & & & Escherichia coli IS1 (46\%) & Umeda and Ohtsubo 1991 \\
\hline
\end{tabular}

\footnotetext{
${ }^{a}$ Open reading frames (ORF) of transposases. With the exception of ISEh1, all IS elements contained two putative transposases, designated A and B.
}

${ }^{\mathrm{b}}$ Percent homology in amino acid 
reached five or six copies (Fig. 2, Table 2). Interestingly, the nonpathogenic Eh3-1 is apparently an isogenic strain of Ehg31a that resulted from the loss of pPATH $\mathrm{Fh}_{\text {Eh }}$ (Table 3 ). Thus, the IS elements that are present in Ehg3-1a and are absent in Ehg31 are most likely located on pPATH Ehg. .

The AvrPphD Eng and its effect on pathogenicity.

DNA sequence analysis of the hrp flanking region between ISEhe 3 and IS 1327 (Fig. 1B) revealed an ORF of 2,118 bp encoding a deduced peptide product of 706 aa with a predicted molecular mass of $75.45 \mathrm{kDa}$. A putative hrp box was identified 42 bp upstream of the start codon. The ORF showed $89 \%$ identity in amino acids to AvrPphD of Pseudomonas syringae pv. phaseolicola, which contains an ORF of 2,130 bp and encodes a peptide product of 710 aa (Arnold et al. 2001). The $\mathrm{G}+\mathrm{C}$ content of the $a v r P p h D_{\text {Ehg }}$ was $52.3 \%$, compared with $55 \%$ of Pseudomonas syringae pv. phaseolicola. The nucleotide sequence of the $a v r P p h D_{\text {Ehg }}$ was submitted to GenBank as accession number AF462346. This gene has also been isolated

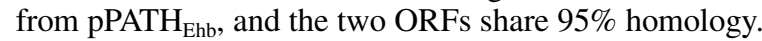

In order to examine the effect of $a v r P p h D_{\text {Ehg }}$ on the pathogenicity of Erwinia herbicola pv. gypsophilae, the marker exchange mutant Ehg824-1Mx(Km-avrPphD Ehg $)$ was generated by inserting a kanamycin-resistant $\left(\mathrm{Km}^{\mathrm{r}}\right)$ cassette into the ORF of $a v r P p h D_{\text {Ehg. }}$ The obtained mutant was then tested for pathogenicity on gypsophila cuttings. The results illustrated in Figure 3 clearly demonstrated that this mutant substantially reduced gall size in gypsophila compared with that in the wildtype strain. Measurements on six replicates per treatment showed that the galls in the wild-type Ehg824-1 weighed an average of $50 \pm 18 \mathrm{mg}$ after 12 days compared with $7.5 \pm 0.2 \mathrm{mg}$ in the mutant. Similar reductions of approximately $85 \%$ in gall size were obtained in three independent experiments. Pathogenicity of the mutant could be restored almost to the wildtype level by complementation with pLA150 in trans (Fig. 3). The marker exchange mutant $\operatorname{Ehg} 824-1 \mathrm{Mx}\left(\mathrm{Km}-a v r P p h D_{\text {Ehg }}\right)$ was also tested for hypersensitive response (HR) elicitation on tobacco leaves (Nicotiana tabacum L. Hicks) as described previously (Nizan et al. 1997). The mutant elicited the HR response, as did the wild-type strain (results not shown).

\section{DISCUSSION}

The presence of an assembly of six different IS elements, including IS1327 (Lichter et al. 1996), in the flanking regions of the $h r p$ gene cluster and of the IAA operon on pPATH $_{\text {Ehg }}$ (Fig. 1) provides strong evidence that an intensive horizontal gene transfer may have taken place during the evolution of the pathogenicity plasmid. Studies of the mechanisms of bacterial pathogenesis have demonstrated associations between ISs and many pathogenic and virulence functions. Such associations have been observed in animal pathogens, e.g., Bacillus (Mahillon et al. 1994), Yersinia (Filippov et al. 1990), and Escherichia (Hu and Lee 1988); plant pathogens, e.g., Agrobacterium (Otten et al. 1992) and Pseudomonas (Yamada et al. 1986); and symbionts, e.g., Rhizobium (Freiberg et al. 1997). The clustering of various IS elements in "islands" within plasmid genomes has also been observed frequently (Mahillon and Chandler 1998) and may serve to promote plasmid integration, excision, and other rearrangements.

We have previously shown that multiple copies of IS1327 are found only in $\mathrm{pPATH}_{\mathrm{Ehg}}$ and $\mathrm{PPATH}_{\mathrm{Ehb}}$ (Lichter et al. 1996). The observation that multiple copies of ISEhe1, ISEhe2, ISEhe3, and ISEhe 5 are present only in pathogenic strains of Erwinia herbicola pv. gypsophilae and Erwinia herbicola pv. betae and are not present in nonpathogenic strains that lack pPATH (Table 2) could imply that they are confined to the pathogenicity plasmids in both pathovars. Comparison of IS elements in the pathogenic strain Ehg3-1a with those in its isogenic and nonpathogenic counterpart Eh3-1 corroborates this hypothesis. The latter results may suggest that these IS elements participated in the evolution of pPATH. In contrast, ISEhe 4 was present in both pathogenic and nonpathogenic strains and might not necessarily have been involved in the for mation of pPATH. The apparent specificity
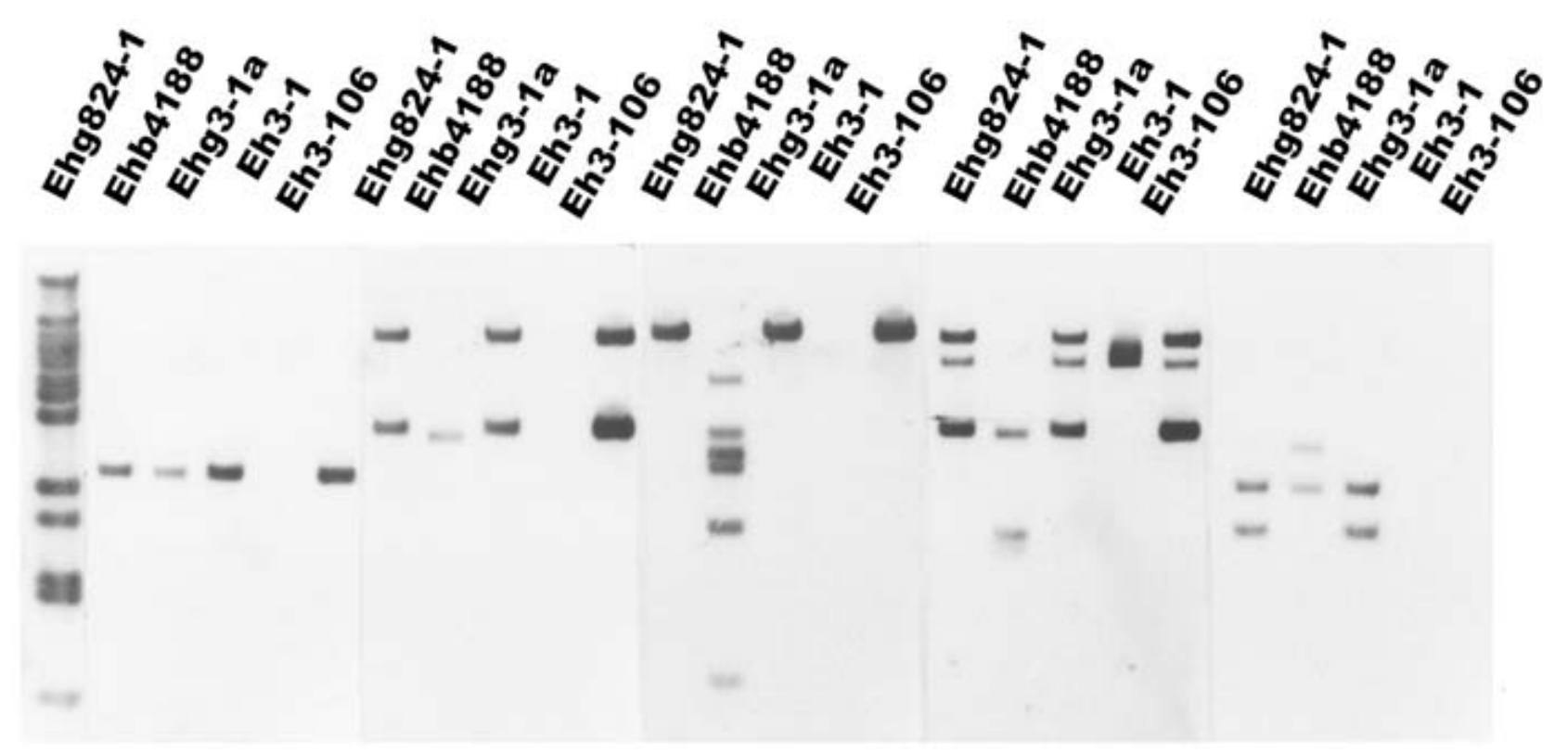
ISEhe1
ISEhe2
ISEhe3
ISEhe4
ISEhe5

Fig. 2. Southern blot hybridization showing the distribution of ISEhe1, ISEhe2, ISEhe3, ISEhe4, and ISEhe5 in different Erwinia herbiocola strains. Total DNA was digested with HindIII and hybridized with probes of each of the IS elements (ISEhel to ISEhe5). Ehg 824-1, Ehg 3-1a, and Ehb 4188 are pathogenic, whereas Eh 3-1 and Eh3-106 are nonpathogenic strains. Left lane, $\lambda$ BstEI DNA digest. 
of IS1327 and ISEhe1, ISEhe2, ISEhe3, and ISEhe5 to the pPATH could result from their inability to transpose to other plasmids or to chromosomal DNA. Alternatively, these IS elements may have been actively distributed on the pPATH prior to its acquisition by Erwinia herbicola, in which they became inactive. At present, we do not have evidence to support current transposition of these IS elements, although copies of IS1327 have been transcribed and their transcripts may accommodate the transposase size (Lichter et al. 1996). Detailed research would be required to determine whether the observed polymorphism in IS elements between pPATH $\mathrm{Ehg}_{\text {and }}$ aPATH $\mathrm{Phb}_{\text {Ehb }}$ which is manifested in fragment size in the case of IS1327 and in copy number in the case of IS1327 (Lichter et al. 1996) and ISEhe3 (Table 2), could result from active transposition or from rearrangements of plasmids after segregation of the pathovars. Nevertheless, the hypothesis of a common origin of pPATH in the two pathovars (Ezra et al. 2000) is supported by the presence of the same IS elements as well as by the presence of common virulence genes on both plasmids (Lichter et al. 1995a; Mor et al. 2001; Valinsky et al. 1998; I. Barash and S. Manulis unpublished data).

AvrPphD, which was originally isolated from Pseudomonas syringae pv. phaseolicola, is widely distributed in almost all Pseudomonas syringae pathovars (Arnold et al. 2001). Homologues of avrPphD have also been identified in Xanthomonas

Table 2. Number of copies of IS elements in pathogenic and nonpathogenic Erwinia herbicola strains

\begin{tabular}{|c|c|c|c|c|c|c|c|c|c|}
\hline \multirow[b]{3}{*}{ IS } & \multicolumn{9}{|c|}{ Number of copies of IS elements ${ }^{a}$} \\
\hline & \multicolumn{3}{|c|}{ Pathogenic strains } & \multicolumn{6}{|c|}{ Nonpathogenic strains } \\
\hline & Ehg824-1 & $E h b 4188$ & Ehg3-1a & Eh3-1 & Eh24-8 & $E h K 4$ & Eh27-3 & Eh717-2 & Eh3-106 \\
\hline ISEhe 1 & 1 & 1 & 1 & 0 & 0 & 0 & 0 & 0 & 1 \\
\hline ISEhe2 & 2 & 1 & 2 & 0 & 0 & 0 & 0 & 0 & 2 \\
\hline ISEhe3 & 1 & 5 to 6 & 1 & 0 & 0 & 0 & 0 & 0 & 1 \\
\hline ISEhe 4 & 3 & 2 & 3 & 1 & 0 & 1 & 2 & 2 & 3 \\
\hline ISEhe 5 & 2 & 2 & 2 & 0 & 0 & 0 & 0 & 0 & 0 \\
\hline
\end{tabular}

a The total DNA of pathogenic strains Ehg 824-1, Ehg 3-1a, and Ehb 4188 and nonpathogenic strains Eh 3-1, Eh24-8, Eh K4, Eh 27-3, Eh 717-2, and Eh3-106 was digested with EcoRI, HindIII, and BamHI, separately. Following gel electrophoresis, each digest was subjected to Southern blot hybridization with probes for each of the five IS elements. The number of copies were determined from the number of bands observed after Southern blotting. Eh3-106 is a Tn5 derivative of Ehg824-1 with a deletion of 40 to $50 \mathrm{~kb}$ in the $\mathrm{pPATH}_{\text {Ehg }}$ upstream to the etz gene.

Table 3. Bacterial strains, cosmids, and plasmids ${ }^{\mathrm{a}}$

\begin{tabular}{|c|c|c|}
\hline Strain/plasmid & Relevant characteristics & Reference or source \\
\hline \multicolumn{3}{|l|}{ Escherichia coli } \\
\hline DH5 $\alpha$ & RecA, lacZA, M15 & Hanahan 1983 \\
\hline \multicolumn{3}{|l|}{ Erwinia herbicola (Eh) } \\
\hline Ehg824-1 & Rif $^{\mathrm{T}}$, wild-type pathogenic strain, gypsophila pathovar & Manulis et al. 1991 \\
\hline Ehb4188 & Rif $^{\mathrm{T}}$, wild-type pathogenic strain, beet pathovar & Burr et al. 1991 \\
\hline Ehg3-1a & Wild-type, pathogenic strain, gypsophila pathovar & Manulis et al.1991 \\
\hline Eh3-106 & Ehg824-1::Tn5, $\mathrm{Km}^{\mathrm{r}}$, nonpathogenic, a 40 to $50-\mathrm{kb}$ deletion in $\mathrm{pPATH}_{\mathrm{Ehg}}$ & Lichter et al.1995b \\
\hline Eh3-1 & Nonpathogenic strain, a derivative of Ehg3-1a & Lichter et al.1995a \\
\hline Eh24-8 & Wild-type, nonpathogenic strain & Manulis et al.1991 \\
\hline EhK4 & Wild-type, nonpathogenic strain & Manulis et al.1991 \\
\hline Eh $27-3$ & Wild-type, nonpathogenic strain & Manulis et al.1991 \\
\hline Eh717-2 & Wild-type, nonpathogenic strain & Manulis et al.1991 \\
\hline Ehg824-1Mx (Km-avrPphD Ehg $)$ & $\mathrm{Km}^{\mathrm{r}}$, marker exchange mutant of $\mathrm{Km}^{\mathrm{r}}$ cassette in avrPphD $\mathrm{Dhg}_{\mathrm{E} g}$ & This study \\
\hline \multicolumn{3}{|c|}{ 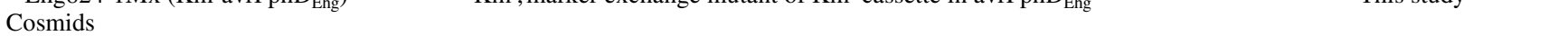 } \\
\hline pLAFR3 & $\mathrm{Tc}^{\mathrm{r}}$, broad-host-range vector IncP-1 rlx RK2 $2^{+}$lacZ $\alpha \mathrm{Tra}^{-} \mathrm{Mob}^{+} \mathrm{cos}$ & $\begin{array}{l}\text { Staskawicz et al. } \\
1987\end{array}$ \\
\hline pLA150 & $\mathrm{Tc}^{\mathrm{r}}$, a $28-\mathrm{kb}$ cosmid clone in pLAFR3 & Lichter et al.,1995a \\
\hline pLG101 & $\begin{array}{l}\mathrm{Tc}^{\mathrm{r}}, 7.5-\mathrm{kb} \text { EcoRI fragment from pLA150 cloned into pLAFR3, covering iaaM, } \\
\text { iaaH, and part of cytokinin operon }\end{array}$ & Clark et al. 1993 \\
\hline $\begin{array}{l}\text { pLA-H2.4, pLA-H1.8, pLA-H9, } \\
\text { pLA-H7.3, pLA-H2.8, and pLA-H4.1 }\end{array}$ & $\mathrm{Tc}^{\mathrm{r}}$, HindIII-digested fragments of pLA150 subcloned into pLAFR3 & This study \\
\hline pLA-B/H3.8 & $\mathrm{Tc}^{\mathrm{r}}$, a $3.8-\mathrm{kb}$ BamHI/HindIII fragment of pLA-H7.3 subcloned into pLAFR3 & This study \\
\hline pLA-B/H3.0 & $\mathrm{Tc}^{\mathrm{r}}$, a 3.0-kb Bam HI/HindIII fragment of pLA-H7.3 subcloned into pLAFR3 & This study \\
\hline pLA-B4.5 & $\mathrm{Tc}^{\mathrm{r}}$, a $4.5-\mathrm{kb}$ Bam $\mathrm{HI}$ fragment of pLG101 subcloned into pLAFR3 & This study \\
\hline pLA-R/H5.5 & $\mathrm{Tc}^{\mathrm{r}}$, a 5.5 EcoRI/HindIII fragment of pLA-H9 subcloned into pLAFR3 & This study \\
\hline \multicolumn{3}{|l|}{ Plasmids } \\
\hline pBluescript KS & $A m p^{r}$, subcloning and sequencing vector & $\begin{array}{l}\text { Stratagene } \\
\text { La Jolla, CA, U.S.A. }\end{array}$ \\
\hline pMBG-H/P2.5 & $\mathrm{Amp}^{\mathrm{r}}$, a $2.5-\mathrm{kb}$ HindIII/PstI fragment of pLA-R/H5.5 subcloned into into $\mathrm{KS}^{+}(\mathrm{pBS})$ & This study \\
\hline pMBG-H/P1.7 & $\mathrm{Amp}^{\mathrm{r}}$, a $1.7-\mathrm{kb}$ HindIII/PstI fragment of pLA-B/H3.8 subcloned into $\mathrm{KS}^{+}(\mathrm{pBS})$ & This study \\
\hline pMBG-R/B2.8 & $\mathrm{Amp}^{\mathrm{r}}$, a $2.8-\mathrm{kb} E c o \mathrm{RI} /$ BamHI fragment of pLA-B/H3.8 subcloned into $\mathrm{KS}^{+}(\mathrm{pBS})$ & This study \\
\hline pMBG-B/H3.0 & $\mathrm{Amp}^{\mathrm{r}}$, a 3.0-kb BamHI/HindIII fragment of pLA-H7.3 subcloned into $\mathrm{KS}^{+}(\mathrm{pBS})$ & This study \\
\hline pMBG-R/H1.1 & $\mathrm{Amp}^{\mathrm{r}}$, a 1.1-kb EcoRI/HindIII fragment of pLA-H2.8 subcloned into $\mathrm{KS}^{+}(\mathrm{pBS})$ & This study \\
\hline pMBG-R/H1.5 & $\mathrm{Amp}^{\mathrm{r}}$, a 1.5-kb EcoRI/HindIII fragment of pLA-H2.8-kb subcloned into $\mathrm{KS}^{+}(\mathrm{pBS})$ & This study \\
\hline $\mathrm{pMBG}-\mathrm{B} / \mathrm{K} 2.4$ & $\begin{array}{l}\text { Amp } p^{\mathrm{r}} \text {, a } 2.4-\mathrm{kb} \text { BamHI/KpnI fragment of pLA-B4.5 subcloned into } \mathrm{KS}^{+}(\mathrm{pBS}) \mathrm{KS}^{+} \\
(\mathrm{pBS})\end{array}$ & This study \\
\hline pMBG-B/K2.5 & $\mathrm{Amp}^{\mathrm{r}}$, a $2.5-\mathrm{kb}$ BamHI/KpnI fragment of pLA-B4.5 subconed into $\mathrm{KS}^{+}(\mathrm{pBS})$ & This study \\
\hline pMBG-H2.4 & $\mathrm{Amp}^{\mathrm{r}}$, a 2.4 HindIII fragment of pLA-H2.4 subcloned into $\mathrm{KS}^{+}(\mathrm{pBS})$ & This study \\
\hline pMBG-H1.8 & $\mathrm{Amp}^{\mathrm{r}}$, a 1.8 HindIII $1.8 \mathrm{~kb}$ fragment of pLA-H1.8 subcloned into $\mathrm{KS}^{+}(\mathrm{pBS})$ & This study \\
\hline
\end{tabular}

${ }^{a}$ Antibiotics were used in the following concentrations ( $\left.\mu \mathrm{g} / \mathrm{ml}\right)$ : ampicillin (Amp), 100; kanamycin (Km), 50; rifampicin (Rif), 100 ; and tetracycline (Tc), 12. 
campestris pv. vesicatoria (Noel et al. 2001) and in the genome sequence of Ralstonia solanacearum. However, in spite of its prevalence in three major phytopathogenic bacterial species, the involvement of avrPphD in virulence has never been reported. In the present study, we have not only demonstrated the presence of an $a v r P p h D_{\text {Ehg }}$ in a new bacterial species but have also shown that it functions as a virulence factor in Erwinia herbicola pv. gypsophilae. Interestingly, gall reduction in gypsophila $(85 \%)$ obtained by the $a v r P p h D_{\text {Ehg }}$ mutant was significantly higher than the approximately $50 \%$ reduction obtained by mutants deficient in production of either cytokinins or IAA, or both (Manulis et al. 1998). The presence of a hrp box in the promoter region of the gene suggests that it acts as a type III virulence effector. Further work will be required to elucidate the mode of action of AvrPphD $\mathrm{Dhg}_{\text {in }}$ gall formation by Erwinia herbicola pv. gypsophilae.

Hacker and associates (1997) defined PAIs as gene clusters that exhibit the following characteristics: (i) they include many virulence genes; (ii) they are present in pathogenic but not in closely related nonpathogenic strains; (iii) they have a different $\mathrm{G}+\mathrm{C}$ content from that of the host bacteria DNA; (iv) they occupy large chromosomal regions; (v) they contain (often cryptic) 'mobility' genes (IS elements, transposases, integrases); (vi) there is association with tRNA genes or IS elements, or both, in their boundaries; and (vii) they are unstable. Current and previous data on the organization and nature of the mobile elements and virulence genes on the $\mathrm{PPATH}_{\text {Ehg }}$ plasmid comply with the major criteria for a PAI definition and unequivocally
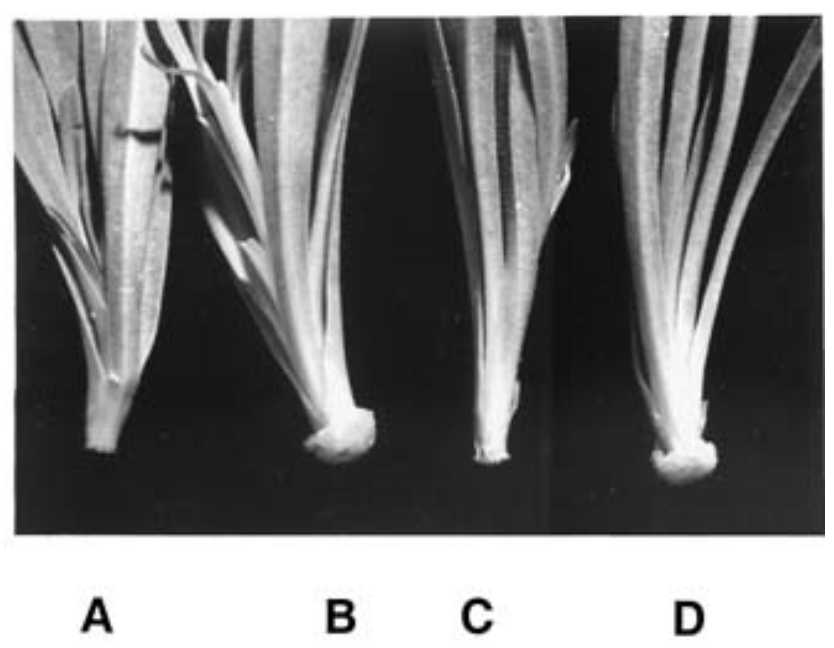

Fig. 3. Phenotypic expression of insertional kanamycin-resistant cassette in $\operatorname{avr} P p h D_{\text {Ehg }}$ following inoculation of gypsophila cuttings. A, water control; B, wild type, Ehg824-1; C, marker exchange mutant Ehg824$1 \mathrm{Mx}\left(\mathrm{Km}-a v r P p h D_{\mathrm{Eh}}\right)$; and $\mathbf{D}$, complementation of Ehg824-1Mx (KmavrPph $D_{\text {Ehg }}$ ) with pLA150. confirm the presence of a PAI. Evidence that substantiates this conclusion is based on the following findings: (i) as indicated above, all the virulence genes that have so far been character-

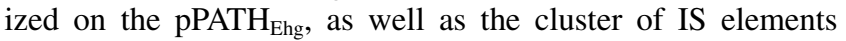
demonstrated in the present study, are assembled on three consecutive overlapping cosmids that occupy approximately $55 \mathrm{~kb}$ of the plasmid (Fig. 1), (ii) with the exception of ISEhe4, all the IS elements are present in pathogenic but not in nonpathogenic strains, and (iii) the range of the $\mathrm{G}+\mathrm{C}$ content of ISEhel, ISEhe2, ISEhe3, and ISEhe5 extends from 51.24 to $43.93 \%$ and is significantly lower than the characteristic $\mathrm{G}+\mathrm{C}$ contents of the species (55 to 56.8\%) (Gavini et al. 1989). Similarly, the $\mathrm{G}+\mathrm{C}$ contents of all the characterized virulence genes are significantly different from those of the species. Thus, the range of $\mathrm{G}+\mathrm{C}$ content of the various virulence genes are: operons of the $h r p$ cluster, from 51.8 to $47.8 \%$ (Mor et al. 2001); IAA operon, 50.3 to $52.8 \%$ (Gafni et al. 1997); cytokinin operon, 34.8 to $41.3 \%$; (Lichter et al. 1995a); $h s v G, 65.4 \%$ (Valinsky et al. 1998); pthG, 51.58\% (Ezra et al. 2000); dspAE/BF, $49.9 \%$ (Mor et al. 2001); and $a v r P p h D_{\text {Ehg }}, 52.6 \%$. Further evidence of the foreign nature of the DNA that forms the PAI on pPATH $\mathrm{Eng}_{\mathrm{E}}$ was provided by the identification of remnants from known genes of Yersinia, Xylella, Actinobacillus and Escherichia spp. (Fig. 1). The existence of the type III system (Mor et al. 2001) reinforces the characterization of the PAI on $\mathrm{pPATH}_{\text {Ehg. Type }}$ III systems have been shown to act as major components in many PAIs of gram-negative bacteria that are pathogenic on animals and plants (Galan and Collmer 1999; Hueck 1998). The possibility that additional genetic loci associated with virulence will be discovered prevents the precise delimitation of the plasmid-borne PAI in Erwinia herbicola pv. gypsophilae.

Erwinia herbicola is widespread in numerous and diverse natural microenvironments (Gavini et al. 1989). It appears that many different bacteria that presumably encountered Erwinia herbicola in its various habitats have left their fingerprints on its genome via mobile elements such as plasmids and insertion sequences and have been instrumental in its conversion from an epiphyte into a biotrophic and gall-forming pathogen.

\section{MATERIALS AND METHODS}

\section{Bacterial strains, plasmids, and growth conditions.}

The bacterial strains and plasmids used in the present study are listed in Table 3. Bacteria were grown in Luria Bertani (LB) broth or on LB agar plates, with appropriate antibiotics, at $28^{\circ} \mathrm{C}$ for Erwinia herbicola and at $37^{\circ} \mathrm{C}$ for E. coli. Genetic manipulations were carried out in Escherichia coli $\mathrm{DH} 5 \alpha$ (Hanahan 1983).

\section{Pathogenicity tests.}

Pathogenicity tests on cuttings of Gypsophila paniculata cvs. Festival or Golan were essentially as described previously (Lichter et al. 1995a). After removal of an approximately 3-mm

Table 4. Polymerase chain reaction (PCR) primers used for obtaining IS probes

\begin{tabular}{|c|c|c|c|c|}
\hline Primer & Sequence $\left(5^{\prime}-3^{\prime}\right)$ & Source $^{a}$ & IS element & IS probe (bp) \\
\hline $1 \mathrm{~A}$ & ATGGTGAAACTGGGCTGC & pMBG-R/H1.1 & ISEhe 1 & 575 \\
\hline $1 \mathrm{~B}$ & ATCACCAGCCGGACTGAG & pMBG-R/H1.1 & & \\
\hline $2 \mathrm{~A}$ & TGTCCCTTAATCACCTGAG & $\mathrm{pMBG}-\mathrm{B} / \mathrm{H} 3.0$ & ISEhe 2 & 598 \\
\hline $2 \mathrm{~B}$ & TCATGCTGCCGTTCTTAC & pMBG-B/H3.0 & & \\
\hline $3 \mathrm{~A}$ & TCCAGCGTTGCAACACGTC & $\mathrm{pMBG}-\mathrm{B} / \mathrm{H} 3.0$ & ISEhe 3 & 655 \\
\hline $3 \mathrm{~B}$ & GAACAGATCAACAACCACGG & $\mathrm{pMBG}-\mathrm{B} / \mathrm{H} 3.0$ & & \\
\hline $4 \mathrm{~A}$ & CCTGCAGGCTGGCAGGTCTG & pMBG-R/B2.8 & ISEhe 4 & 738 \\
\hline $4 \mathrm{~B}$ & TGCAAATTCAGACGGCGTC & pMBG-R/B2.8 & & \\
\hline $5 \mathrm{~A}$ & GTTACCGTCCTCCCGTGC & pMBG-H2.4 & ISEhe 5 & 479 \\
\hline $5 B$ & TGCATATCACAGCCAGCG & pMBG-H2.4 & & \\
\hline
\end{tabular}

${ }^{\mathrm{a}}$ Subclones used as templates for PCR are described in Table 3. 
section from the bottom of the stem, cuttings were inoculated by dipping into a bacterial suspension of $10^{8} \mathrm{CFU} / \mathrm{ml}$ and placed in vermiculite-filled trays. The greenhouse temperature was held at 26 to $28^{\circ} \mathrm{C}$, and computer-controlled mist sprinklers maintained high humidity, as described previously (Lichter et al. 1995a). Gall formation was scored 14 days after inoculation on three or four replicates per strain in three independent experiments.

\section{DNA manipulations.}

Isolation of plasmid DNA from Escherichia coli, restriction enzyme digestions, subcloning, transformation, Southern blot analyses, polymerase chain reactions (PCRs), and minipreparations of total DNA from Erwinia herbicola were carried out by standard procedures (Ausubel et al. 1995). A DNA probe for each IS element was prepared by PCR, with primers synthesized by Gibco BRL (Glasgow, U.K.) (Table 4). Following electrophoresis, DNA product was extracted from the gel with a Glass Powder DNA isolation kit (Biological Industries Co., Beth Halmek, Israel) and was Dig-labeled using a Random Primer Labeling Kit (Roche Molecular Biochemicals, Mannheim, Germany).

Insertional inactivation of $a v r P p h D_{\text {Ehg }}$ was carried out by introducing a $\mathrm{Km}^{\mathrm{r}}$ cassette. pMBG-H/P1.7 (Table 3) was digested by EcoRI and self ligated to obtain a deletion of $316 \mathrm{bp}$. The $\mathrm{Km}^{\mathrm{r}}$ cassette was then inserted into the EcoRI site of the deleted pMBG-H/P1.7 as described elsewhere (Lichter et al. 1995a). This construct was digested with Asp718 and NotI, and the cohesive termini of the restriction sites were then filled with Klenow enzyme to form blunt ends. The resulting fragment was cloned into pLAFR3 that had been predigested with $P s t \mathrm{I}$ and treated with Klenow enzyme to obtain blunt ends. The mutated $a v r P p h D$ in pLAFR3 was mobilized to Ehg824-1 by triparental mating followed by plasmid curing as described previously (Clark et al. 1993) to obtain the marker exchange mutant Ehg824-1Mx (Km-avrPphD $\left.D_{\mathrm{Ehg}}\right)$. Isolation of $a v r P p h D_{\mathrm{Ehb}}$ from the beet pathovar was carried out with the cosmid pLE142 from the plasmid library of Ehb4188, which forms

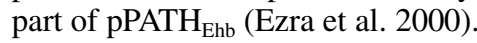

\section{DNA sequencing.}

The HindIII-digested fragments from pLA150 were cloned into pLAFR3 to produce subclones designated as pLA-H2.4, pLA-H1.8, pLA-H9.0, pLA-H7.3, pLA-H2.8, and pLA-H4.1, (Table 3). pLA-H7.3 was further digested with BamHI and HindIII into two fragments of 3.8 and $3 \mathrm{~kb}$ that were cloned into pLAFR3 to yield pLA-B/H3.8 and $\mathrm{pLA}-\mathrm{B} / \mathrm{H} 3$, respectively. A 4.5-kb fragment obtained from pLG101 (Table 3) following digestion with BamHI was cloned into pLAFR3 to generate pLA-B4.5. Similarly, a 5.5-kb fragment obtained by digesting pLA-H9 with EcoRI and HindIII was cloned into pLAFR3 to generate pLA-R/H5.5. The DNA inserts from the above mentioned cosmids were subcloned into pBluescript $\left(\mathrm{KS}^{+}\right)$for sequencing, and the resulting plasmids were designated as $\mathrm{pMBG}$, with a plasmid number indicating the size of the insert (Table 3). The plasmids pMBG-B/K2.4 and pMBG$\mathrm{B} / \mathrm{K} 2.5$ were used for obtaining the sequence described in Figure 1A, whereas pMBG-H/P2.5, pMBG-H/P1.7, pMBGR/B2.8, pMBG-B/H3.0, $\mathrm{pMBG}-\mathrm{R} / \mathrm{H} 1.1, \quad \mathrm{pMBG}-\mathrm{R} / \mathrm{H} 1.5$, pMBG-H2.4, and pMBG-H1.8 were used for obtaining the sequence described in Figure 1B. Automated sequencing with Taq DNA polymerase was carried out at the Laboratories for Biological Services, Tel-Aviv University. Whenever required, walking with custom primers completed the sequence. Sequence data were analyzed with the Wisconsin Package, version 9 (Genetic Computer Group, Madison, WI, U.S.A.), and sequences were then compared with data in the Gene Bank by means of DNA or protein Blast tools at NCBI.

\section{ACKNOWLEDGMENTS}

This research was supported by the Deutsche Forschungsgemeinschaft program for Trilateral Cooperation among Israel, Palestine, and Germany (grant no. EI 1440/11-1) and research grant no. 45-2816-96 from BARD, the U.S.-Israel Binational Agricultural Research and Development Fund.

\section{LITERATURE CITED}

Alfano, J. R., Charkowski, A. O., Deng, W., Badel, J. L., PetnickiOcwieja, T., van Dijk, K., and Collmer, A. 2000. The Pseudomonas syringae Hrp pathogenicity island has a tripartite mosaic structure composed of a cluster of type III secretion genes bounded by exchangeable effector and conserved effector loci that contribute to parasitic fitness and pathogenicity in plants. Proc. Nat. Acad. Sci. U.S.A. 97:48564861 .

Arnold, D. L., Gibbon, M. J., Jackson, R. W., Wood, J. R., Brown, J., Mansfield, J. W., Taylor, J. D., and Vivian, A. 2001. Molecular characterization of avrPphD, a widely-distributed gene from Pseudomonas syringae pv. phaseolicola involved in non-host recognition by pea (Pisum sativum). Physiol. Mol. Plant Pathol. 58:55-62.

Ausubel, F. M., Brent, R., Kingston, R. E., Moore, D. D., Seidman, J. G., Smith, J. A., Struhl, K., eds. 1995. Current Protocols in Molecular Biology. John Wiley \& Sons, Inc., New York.

Bell, C. R., Dickie, G. A., Harvey, W. L. G., and Chan, J. W. Y. F. 1995. Endophytic bacteria in grapevine. Can. J. Microbiol. 41:46-53.

Burr, T. J., Katz, B. H., Abawi, G. S., and Crosier, D. C. 1991. Comparison of tumorigenic strains of Erwinia herbicola isolated from table beet with E. h. gypsophilae. Plant Dis. 75:855-858.

Carniel, E., Guilvout, I., and Prentice, M. 1996. Characterization of a large chromosomal 'high pathogenicity island' in biotype 1B Yersinia enterocolitica. J. Bacteriol. 178:6743-6751.

Cheng, Q., Thomas, S. M., Kostichka, K., Valentine, J. R., and Nagarajan, V. 2000. Genetic analysis of a gene cluster for a cyclohexanol oxidation in Acinetobacter sp. strain SE19 by in vitro transposition. J. Bacteriol. 182:4744-4751.

Clark, E., Manulis, S., Ophir, Y., Barash, I., and Gafni, Y. 1993. Cloning and characterization of iaaM and iaaH from Erwinia herbicola pathovar gypsophilae. Phytopathology 83:234-240.

Cooksey, D. A. 1986. Galls of Gypsophila paniculata caused by Erwinia herbicola. Plant Dis. 70:464-468.

de Meirsman, C., van Soom, C., Verreth, C., van Gool, A., and Vanderleyden, J. 1990. Nucleotide sequence analysis of IS427 and its target sites in Agrobacterium tumefaciens T37. Plasmid 24:227-234.

De Young, R. M., Copeman, R. J., and Hunt, R. S. 1998. Two strains in the genus Erwinia cause galls on Douglas-fir in southern British Columbia. Can J. Plant Pathol. 20:194-200.

Ezra, D., Barash, I., Valinsky, L., and Manulis, S. 2000. The dual function in virulence and host range restriction of a gene isolated from pPATH $_{\text {Ehg }}$ plasmid of Erwinia herbicola pv. gypsophilae. Mol. PlantMicrobe Interact. 13:683-692.

Filippov, A. A., Oleinikov, P. N., Drozdov, A. V., and Protsenko, O. A. 1990. The role of IS elements of Yersinia pestis (Lehmann, Neumann) in the emergence of calcium-independent mutations. Genetika 26:1740-1748.

Freiberg, C., Fellay, R., Bairoch, A., Broughton, W. J., Rosenthal, A., and Perret, X. 1997. Molecular basis of symbiosis between Rhizobium and legumes. Nature 387:397-401.

Gafni, Y., Manulis, S., Kunik, T., Lichter, A., Barash, I., and Ophir, Y. 1997. Characterization of the auxin synthesis genes of Erwinia herbicola pv. gypsophilae. Israel J. Plant Sci. 45:279-284.

Galan, J. E., and Collmer, A. 1999. Type III secretion machines: Bacterial devices for protein delivery into host cells. Science 284:1322-1328.

Gavini, F., Mergaret, J., Beji, A., Mielcarek, C., Izard, D., Kersters, K., and De Ley, J. 1989. Transfer of Enterobacter agglomerans (Beijerinck 1888) Ewing and Fife 1972 to Pantoea gen. nov. as Pantoea agglomerans comb. nov. and description of Pantoea dispersa sp. nov. Int. J. Syst. Bacteriol. 39:337-345.

Gomez, P., Ribas-Aparicio, R. M., Pelaez, A. I., Gomez, A., and Radicio, M. R. 1997. Isolation and nucleotide sequence of the gene encoding the XamI DNA methyltransferase of Xanthomonas campestris pv. amaranthicola. Biochim. Biophys. Acta 1351:261-266.

Hacker, J., and Kaper, J. B. 1999. The concept of pathogenicity islands. Pages 1-11 in: Pathogenicity Islands and Other Mobile Virulence Elements. J. B. Kaper and J. Hacker, eds. ASM Press, Washington, D.C.

Hacker, J., and Kaper, J. B. 2000. Pathogenicity islands and the evolution of microbes. Annu. Rev. Microbiol. 54:641-679.

Hacker, J., Blum-Oehler, G., Mühldorfer, I, and Tschape, H. 1997. Pathogenicity islands of virulent bacteria: Structure, function and impact on microbial evolution. Mol. Microbiol. 23. 
Hanahan, D. 1983. Studies on transformation of Escherichia coli with plasmids. J. Mol. Biol. 166:557-580.

Hu, S. T., and Lee, C. H. 1988. Characterization of the transposon carrying the STII gene of enterotoxigenic Escherichia coli. Mol. Gen. Genet. 214:490-495.

Hueck, H. C. 1998. Type III protein secretion systems in bacterial pathogens of animals and plants. Microbiol. Mol. Biol. Rev. 62:379-433.

Hu-Shu, H. H., and Malabi, M. V. 1998. Genetic analysis of Shigella sonnei form I antigen: Identification of a novel IS630 as an essential element for the form I antigen expression. Microb. Pathog. 25:165-173.

Iriarte, M., and Cornelis, G. R. 1999. The 70-kilobase virulence plasmid of Yersiniae. Pages 91-126 in: Pathogenicity Islands and Other Mobile Virulence Elements. J. B. Kaper and J. Hacker, eds. American Society for Microbiology Press, Washington, D. C

Jackson, R. W. Athanassopoulos, E., Tsiamis, G., Mansfield, J. W. Sesma, A., Arnold, D. L., Gibbon, M. J., Murillo, J., and Vivian, A. 1999. Identification of a pathogenicity island, which contains genes for virulence and avirulence, on a large native plasmid in the bean pathogen Pseudomonas syringae pathovar phaseolicola. Proc. Natl. Acad. Sci. U.S.A. 96:10875-10880.

Krause, M., Harwood, J., Fierer, J., and Guiney, D. 1991. Genetic analysis of the homology between the virulence plasmids of Salmonella dublin and Yersinia pseudo tuberculosis. Infect. Immun. 59:18601863.

Lee, Y. A., and Chiu S. P. 1998. IS1403 and IS1404: Analysis and distribution of two new insertion sequences in Xanthomonas campestris. Bot. Bull. Acad. Sinica (Taiwan) 39:231-239.

Lichter, A., Barash, I., Valinsky, L., and Manulis, S. 1995a. The genes involved in cytokinin biosynthesis in Erwinia herbicola pv. gypsophilae: Characterization and role in gall formation. J. Bacteriol. 177:44574465.

Lichter, A., Manulis, S., Sagee, O., Gafni, Y., Gray, J., Meilan, R., Morris, R. O., and Barash, I. 1995b. Production of cytokinins by Erwinia herbicola pv. gypsophilae and isolation of a locus conferring cytokinin biosynthesis. Mol. Plant- Microbe Interact. 8:114-121.

Lichter, A., Manulis, S., Valinsky, L., Karniol, B., and Barash, I. 1996. IS1327, a new insertion-like element in the pathogenicity-associated plasmid of Erwinia herbicola pv. gypsophilae. Mol. Plant-Microbe Interact. 9:98-104.

Mahillon, J., and Chandler, M. 1998. Insertion sequences. Microbiol Mol. Biol. Rev. 62:725-774.

Mahillon, J., Rezohazy, R., Hallet, B., and Delcour, J. 1994. IS231 and other Bacillus thuringiensis transposable elements: A review. Genetica 93:13-26.

Manulis, S., Gafni, Y., Clark, E., Zutra, D., Ophir, Y., and Barash, I. 1991. Identification of a plasmid DNA probe for detection of Erwinia herbicola pathogenic on Gypsophila paniculata. Phytopathology 81:54-57.

Manulis, S., Haviv-Chesner, A., Brandl, M. T., Lindow, S. E., and Barash, I. 1998. Differential involvement of indole-3-acetic acid biosynthetic pathways in pathogenicity and epiphytic fitness of Erwinia herbicola pv. gypsophilae. Mol. Plant-Microbe Interact. 11:634-642.

Mariani, F., Piccolella, E., Colizzi, V., Rappuoli, R., and Gross, R. 1993. Characterization of an IS-like element from Mycobacterium tuberculosis. J. Gen. Microbiol. 139:1767-1772.

Matsutani, S., Ohtsubo, H., Maeda, Y., and Ohtsubo, E. 1987. Isolation and characterization of IS elements repeats in the bacterial chromosome. J. Mol. Biol. 196:445-455.

McGhee, G. C., and Jones, A. L. 2000. Complete nucleotide sequence of ubiquitous plasmid pEA29 from Erwinia amylovora strain Ea88: Gene organization and intraspecies variation. Appl. Environ. Microbiol. 66:4897-4907.

Mecsas, J., and Strauss, E. J. 1996. Molecular mechanisms of bacterial virulence: Type III secretion and pathogenicity islands. Emerg. Infect. Dis. 2:271-288

Mor, H., Manulis, S., Zuc, M., Nizan, R., Coplin, D. L., and Barash, I. 2001. Genetic organization of the $h r p$ gene cluster and dspAE/BF operon in Erwinia herbicola pv. gypsophilae. Mol. Plant-Microbe Interact. 14:431-436.

Nizan, R., Barash, I., Valinsky, L., Lichter, A., and Manulis, S. 1997. The presence of $h r p$ genes on the pathogenicity-associated plasmid of the tumorigenic bacterium Erwinia herbicola pv. gypsophilae. Mol. PlantMicrobe Interact. 10:677-682.

Noel, L., Thieme, F., Nennstiel, D., and Bonas, U. 2001. cDNA-AFLP analysis unravels a genome-wise $h r p G$-regulon in the plant pathogen Xanthomonas campestris pv. vesicatoria. Mol. Microbiol. 41:12711281.

Ohtsubo, H., Nyman, K., Doroszkiewicz, W., and Ohtsubo, E. 1981. Multiple copies of iso-insertion sequences of IS1 in Shigella dysenteriae chromosome. Nature 292:640-643.

Opgenorth, D. C., Hendson, T. M., and Clark, E. 1994. First report of a bacterial gall of a Wisteria sinensis caused by Erwinia herbicola pv. milletiae in California. Plant Dis. 78:1217.

Otten, L., Canaday, J., Gérard, J.-C., Fournier, P., Crouzet, P., and Paulus, F. 1992. Evolution of agrobacteria and their Ti plasmids-A review. Mol. Plant-Microbe Interact. 5:279-287.

Otten, L., and Schmidt, J. 1998. A T-DNA from the Agrobacterium tumefaciens limited-host-range strain $\mathrm{AB} 2 / 73$ contains a single oncogene. Mol. Plant-Microbe Interact. 11:335-342.

Parsot, C., and Sansonetti, J. 1999. The virulence plasmid of Shigellae: An archipelago of pathogenicity islands. Pages 151-165 in: Pathogenicity Islands and Other Mobile Virulence Elements. J. Hacker and J. B. Kaper, eds. . American Society for Microbiology Press, Washington, D. C.

Priefer, U. B., Kalinowski, J., Ruger, B., Heumann, W., and Puhler, A. 1989. ISR1, a transposable DNA sequence resident in Rhizobium class IV strains, shows structural characteristics of classical insertion elements. Plasmid 21:120-128.

Redenbach, M., Kieser, H. M., Denapaite, D., Eichner, A., Cullum, J., Kinashi, H., and Hopwood, D. 1996. A set of ordered cosmids and detailed genetic and physical map for the $8 \mathrm{Mb}$ Streptomyces coelicolor A3(2) chromosome. Mol. Microbiol. 21:77-96.

Starr, M., P. 1981. The genus Erwinia. Pages 1260-1271 in: The Prokaryotes. M. P. Star., H. G. Truper, A. Balows, and H. G. Schlegel, eds. Springer-Verlag, Berlin.

Staskawicz, B., Dhalbeck, D., Keen, N., and Napoli, C. 1987. Molecular characterization of cloned avirulence genes from race 0 and race 1 of Pseudomonas syringae pv. glycinea. J. Bacteriol. 169:5789-5794.

Steibl, H. D., and Lewecke, F. M. 1995. IS1222: Analysis and distribution of a new insertion sequence in Enterobacter agglomerans 339. Gene 156:37-42.

Umeda, M., and Ohtsubo, E. 1991. Four types of IS1 with differences in nucleotide sequence reside in the Escherichia coli K-12 chromosome. Gene 98:1-5.

Valinsky, L., Manulis, S., Nizan, R., Ezra, D., and Barash, I. 1998. A pathogenicity gene isolated from the pPATH plasmid of Erwinia herbicola pv. gypsophila determines host specificity. Mol. Plant-Microbe Interact. 11:753-762.

Vasanthakumar, A., and McManus, P. C. 2001. Etiology of craneberry stem gall. Abstr. No. 228. 10th International Congress on Molecular Plant-Microbe Interactions. University of Wisconsin, Madison, WI, U.S.A.

Volcani, Z. 1985. Page 388 in: Bacterial Diseases of Plants in Israel. Agricultural Research Organization, The Volcani Center, Bet Dagan, Israel.

Winans, S. C., Kalogeraki, V., Jafri, S., Akakura, R., and Xia, Q. 1999. Diverse roles of Agrobacterium Ti plasmid-borne genes in the formation and colonization of plant tumors. Pages 289-307 in: Pathogenicity Islands and Other Mobile Virulence Elements. J. B. Kaper and J. Hacker, eds. . American Society for Microbiology Press, Washington, D. C.

Wood, M. S., Byrne, A. M., and Lessie, T. G. 1991. IS406 and IS407, two gene-activating insertion sequences from Pseudomonas cepacia. Gene 105:101-105.

Yamada, T., Lee, P. D., and Kosuge, T. 1986. Insertion sequence elements of Pseudomonas savastanoi: Nucleotide sequence homology with Agrobacterium tumefaciens transfer DNA. Proc. Natl. Acad. Sci. U.S.A. 83:8263.

\section{AUTHOR-RECOMMENDED INTERNET RESOURCES}

INRA IS Finder Database: http://www-is.biotoul.fr

National Center of Biotechnology Information website: www.ncbi.nlm. nih.gov/

Ralstonia solanacearum BLAST Server: sequence.toulouse.inra. fr/ralsto/ public/doc/RalstoForm.html 